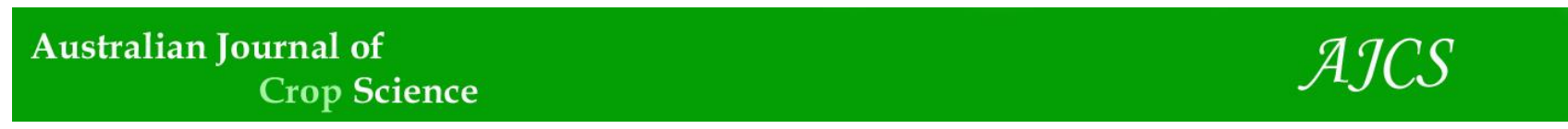

AJCS 13(09):1401-1408 (2019)

ISSN:1835-2707

doi: 10.21475/ajcs.19.13.09.p1174

\title{
Effects of arbuscular mycorrhizal fungi (Glomus mosseae) on growth enhancement and nutrient (NPK) uptake of three grape (Vitis vinifera L.) cultivars under three different water deficit levels
}

\author{
Azimeh Kamayestani ${ }^{1}$, Mehdi Rezaei ${ }^{1 *}$, Ali Sarkhosh ${ }^{2}$, Hamid Reza Asghari ${ }^{1}$ \\ ${ }^{1}$ Faculty of Agriculture, Shahrood University of Technology, P.O. Box 3619995161, Shahrood, Iran \\ ${ }^{2}$ Horticultural Sciences Department, University of Florida, Gainesville FL 32611 USA
}

*Corresponding author: mhrezaei@shahroodut.ac.ir

\begin{abstract}
We tested the effects of arbuscular mycorrhizal fungi (AMF) and three levels of water deficit on growth enhancement, physiological performance and nutrient uptake of three local Iranian grape cultivars. Mycorrhizal inoculation (Glomus mosseae) showed a significant increase in grape's growth characteristics, and variation was observed among the cultivars and field capacity percent (FC $\%)$ levels. Mycorrhiza inoculation increased significantly $(p<0.05)$ the number of leaves in 'Pikani' and 'Shahroudi'. The results showed that water deficit significantly increased the chlorophyll index and decreased the stomatal conductance, leaf relative water content (RWC), leaf area index, nitrogen (N\%) content, and increased proline content $(\mathrm{P}<0.05)$. Water deficit and mycorrhiza increased potassium ( $\mathrm{K} \%$ ) in all cultivars and phosphorous ( $\mathrm{P} \%$ ) in two cultivars ('Shahrudi' and 'Keshmeshi') significantly ( $\mathrm{P}<0.05)$. By increasing the water deficit level, 'Shahrudi' and 'Keshmeshi' showed more relative drought resistance than 'Pikani'. The cultivar 'Shahrudi' showed a better symbiotic interaction with mycorrhiza and more resistance to water deficit in some traits in comparison to other two cultivars.
\end{abstract}

Keywords: field capacity, growth characteristics, mycorrhiza, NPK\%, physiological performance.

Abbreviations: Arbuscular mycorrhizal fungi (AMF), field capacity percent (FC), nitrogen ( $N)$, phosphorus (P) and potassium (K), Relative water content (RWC),

Introduction

Grape, (Vitis vinifera L.), is one of the most important fruit crops of the world. A large proportion of vineyards are located in regions with seasonal drought and atmospheric water deficits, together with high temperatures, including Iran (Chaves et al., 2010). The global climatic changes also increase the frequency of heat waves in large parts of the world. Furthermore decrease in annual mean precipitation in many mid-latitude, and dry subtropical regions make it more erratic (Zandalinas et al., 2018). This scenario will affect crops to a greater range and number of abiotic stresses such as drought stress which is the primary cause of crop loss worldwide, reducing average yields and quality (Awasthi et al., 2014; Teskey et al., 2015). Drought stress has adverse effects on different plant growth parts by hampering key metabolic attributes including nutrient uptake and assimilation, enzyme activity, photosynthesis, protein synthesis and antioxidant metabolism (Hameed et al., 2014; FanizzaRicciardi, 2015). In recent irrigation model of viticulture, deficit irrigation emerged as a tool to mitigate the negative impact of drought on yield and quality and to save water (Chaves et al., 2010; FanizzaRicciardi, 2015; Merli et al., 2015). The effect of deficit irrigation on water savings and drought stress varies with the genotype (scion and rootstock), the environmental conditions as well as the adopted agronomic strategies (Permanhani et al., 2016). Moreover deficient irrigation and drought in viticulture reduced the amount of sugar in the berries, and their size (Keller et al., 2016). Several studies indicated that there is wide variations in water use efficiency among grapevine cultivars (Merli et al., 2015; Permanhani et al., 2016; Medrano et al., 2018). The best-adapted grape genotypes in water restriction in semiarid climate have the leaf cooling capacity and high water use efficiency (Chaves et al., 2016). High water use efficiency genotypes avoid dehydration by closing stomata, but under hot spells, they may reach supraoptimal temperatures (Bota et al., 2016). Therefore they must possess high mesophyll resilience to heat stress (Chaves et al., 2016).

Among soil microorganisms, arbuscular mycorrhiza fungi (AMF) are capable of forming symbiotic associations with host plant roots (Trouvelot et al., 2015). AMFs are known to improve water uptake by plants and nutrient uptake at the same time (Kohler et al., 2008; Trouvelot et al., 2015). This mutualistic collaboration is based on biotrophic nutrient exchanges between the plant and the fungal companion. The host plant supplies the partner with carbon from photosynthesis (Trouvelot et al., 2015). The AMF boosts the ability of the plant through an extensive network of hyphae to absorb and accelerate water and minerals from areas unavailable to the plant root system (Hameed et al., 2014; Hashem et al., 2018). AMF communities are highly influenced by the soil characteristics, but also to a smaller 
extent by the host plant development stage (SchreinerMihara, 2009; Balestrini et al., 2010). Thus, this symbiotic helps the plant to grow in the challenging conditions. The effects of mycorrhizal fungi are particularly evident in the soil with low soluble phosphorus and reduced diffusion coefficient due to water stress (Smith et al., 2011). Research results have shown that arbuscular mycorrhizal fungi can increase plant tolerance to the drought by supplying water and nutrient to the host plant (SchreinerMihara, 2009; Hameed et al., 2014; Rouphael et al., 2015; Trouvelot et al., 2015; Essahibi et al., 2018; Hashem et al., 2018; Xu et al., 2018; Zandalinas et al., 2018). AMF from grape roots mainly belongs to the Glomerales group, although other's form can be found in sandy vineyard soils (Balestrini et al., 2010). Arbuscular mycorrhizacolonized grapevine roots can exhibit more efficient water uptake and allow grapevine to cope with water stress. During drought stress, although arbuscular mycorrhiza colonization declined, the biomass and the proline content were higher in arbuscular mycorrhiza plants than in nonarbuscular mycorrhiza plants (Valentine et al., 2006).

Iran is one of the most important grape origins in the world (This et al., 2006) and there are several high-quality local cultivars with very low information about them and AMF interaction. On the other hand, dry weather and drought stress are considered as one of the leading problems of Iranian vineyards. So that, in this research, the effects of AMF colonization was studied on growth enhancement and nutrient (NPK) uptake of three important Iranian grapes cultivars under drought stress.

\section{Results}

\section{Enhancement of growth}

Mean compression of cultivar and water deficit showed that the highest and the lowest numbers of leaves were achieved by 'Pikani' at the water deficit (FC) $80 \%$ and $40 \%$, respectively (Table 1 ). By increasing the drought stress level, the number of leaves reduced significantly from $43 \%$ in 'Keshmeshi' to $63 \%$ in 'Pikani' (Table 1). Table 2 shows that AMF increased the average number of leaves in both 'Pikani' and 'Shahroudi' $23 \%$ and $37 \%$ respectively., in the other hands, fresh and dry leaves weight were significantly reduced in noninoculated 'Pikani' by AMF(Table 2). Mean comparison of cultivar, water deficit and AMF interactions showed that the 'Shahroudi' had the highest number of internode, where the number of internodes decreased significantly in $40 \%$ water deficit (Table 3). The highest fresh and dry weights of the current shoot growth and the cane was observed in 'Shahroudi' AMF inoculated vines in $80 \%$ irrigation period (Table 3). Furthermore, 'Shahroudi' had the longest stem than other two cultivars in all applied treatments (Table 3). The highest fresh and dry stem, and root weight were achieved by 'Shahroudi' at the water deficit of $60 \%$ and $40 \%$ with AMF respectively. 'Shahroudi' also had the highest total weight and fresh and dry weight of roots than two other cultivars (Table 4). 'Keshmeshi' showed to have the most extended root length at the water deficit of $60 \%$ in the inoculated soil (Table 3 ).

\section{Grape physiological performance}

Significant differences $(p \leq 0.05)$ were observed among nonmycorrhizal and mycorrhizal plants for the chlorophyll index. 'Pikani' showed the highest and lowest chlorophyll index under the water deficit of $80 \%$ and $40 \%$ (Table 1). Chlorophyll content decreased significantly in the water deficient condition (Table 1). There were no significant reductions $(p \leq 0.05)$ on stomatal conductance among nonmycorrhizal and mycorrhizal plants under three different water deficit levels. Stomatal conductance was higher in both cultivars 'Shahroudi' and 'Pikani' than 'Keshmeshi' (Table 4) and it was also significantly reduced in the $40 \%$ water deficit (Fig 1). The stomatal conductance in 'Pikani' and 'Keshmeshi' cultivars which are treated with AMF shows a lower reduction than the 'Shahroodi'cultivar (Fig 1). Relative water content (RWC) was significantly different $(p \leq 0.05)$ among studied cultivars and applied water deficit levels (Table 4 \& 5). RWC was higher in 'Keshmeshi' than two other's cultivars (Table 4). The heights and the lowest level of proline were produced at the water deficit of $40 \%$ and $80 \%$ (Table 5). Water deficit treatments had some significant effect $(p \leq 0.05)$ on some growth and physiological characteristics of the studied cultivars (Table 5).

\section{Nutrient enhancement}

The concentration of nitrogen (N\%) was significantly higher ( $p<0.05$ ) at the water deficit of $80 \%$ and $60 \%$ than $40 \%$ (Table 5). AMF plants 'Shahroudi' cultivar had the highest level of phosphorous at the water deficit of $40 \%$ (Fig 2). AMF plants showed significantly higher potassium concentration (K\%) than non-mycorrhizal plants. Table 1 shows the potassium concentration in leaves of study cultivars affected by three water deficit levels.

\section{Correlations}

The correlation analysis among some traits in Table 6 showed that there is a significant positive correlation between leaf relative water content and chlorophyll index, and there is a negative correlation with stomatal conductance. With the decreasing of stomatal opening in leaf, water content increased. Potassium has a negative correlation with chlorophyll index and leaf nitrogen content. Total weight has a positive relationship with nitrogen content. The root length has a positive correlation with stomatal conductance and negative correlation with RWC. Shoot length has a positive correlation with RWC, nitrogen, and veins total weight. The number of nodes increased by increasing of shoot length, total weight, leaf nitrogen content, and RWC.

\section{Discussion}

Results showed that water deficit reduced the number of leaf and internode, fresh and dry weight of leaf and stem growth in the one-year-old vine. These growth characteristics affected by water deficit levels showed less variation for 'Pikani' than other two cultivars 'Shahroudi' and 'Keshmeshi' (Table3). Water deficit can affect plant growth significantly; morphological characteristics such as leaf, shoot, and root are the most affected parts. Thus, they can 
Table 1. The effects of cultivar and water deficit levels (field capacity (FC\%) on number of leaves, potassium, and chlorophyll index of three Iranian grape cultivars.

\begin{tabular}{|c|c|c|c|c|}
\hline Cultivar & Water deficit (FC\%) & No. of leaf & Chlorophyll index & Potassium \% \\
\hline \multirow{3}{*}{ Shahrudi } & 80 & $19.70 \pm 2.69^{\mathrm{abcz}}$ & $20.75 \pm 1.60^{b c}$ & $0.50 \pm 0.048^{\text {cde }}$ \\
\hline & 60 & $19.00 \pm 2.85^{\mathrm{abc}}$ & $21.18 \pm 0.84^{b}$ & $0.64 \pm 0.041^{a b c}$ \\
\hline & 40 & $10.00 \pm 1.36^{d}$ & $21.19 \pm 1.04^{b}$ & $0.59 \pm 0.042^{b c d}$ \\
\hline \multirow{3}{*}{ Pikani } & 80 & $25.20 \pm 1.60^{\mathrm{a}}$ & $27.08 \pm 0.64^{a}$ & $0.39 \pm 0.061^{\mathrm{e}}$ \\
\hline & 60 & $22.5 \pm 2.60^{\mathrm{ab}}$ & $25.10 \pm 3.10^{\mathrm{ab}}$ & $0.69 \pm 0.021^{a b}$ \\
\hline & 40 & $9.30 \pm 1.73^{d}$ & $16.06 \pm 1.23^{c}$ & $0.55 \pm 0.056^{\text {bcde }}$ \\
\hline \multirow{3}{*}{ Keshmeshi } & 80 & $22.10 \pm 1.84^{a b}$ & $22.47 \pm 0.63^{b}$ & $0.46 \pm 0.039^{\mathrm{de}}$ \\
\hline & 60 & $18.30 \pm 2.16^{\mathrm{b}}$ & $24.17 \pm 1.51^{\mathrm{ab}}$ & $0.44 \pm 0.029^{\mathrm{de}}$ \\
\hline & 40 & $12.55 \pm 1.68^{c}$ & $20.90 \pm 1.55^{c d}$ & $0.77 \pm 0.099^{a}$ \\
\hline
\end{tabular}

${ }^{2}$ Mean \pm Standard Error., Different letters within columns indicate significant differences among the treatments according to Duncan Test $(P<0.05)$.

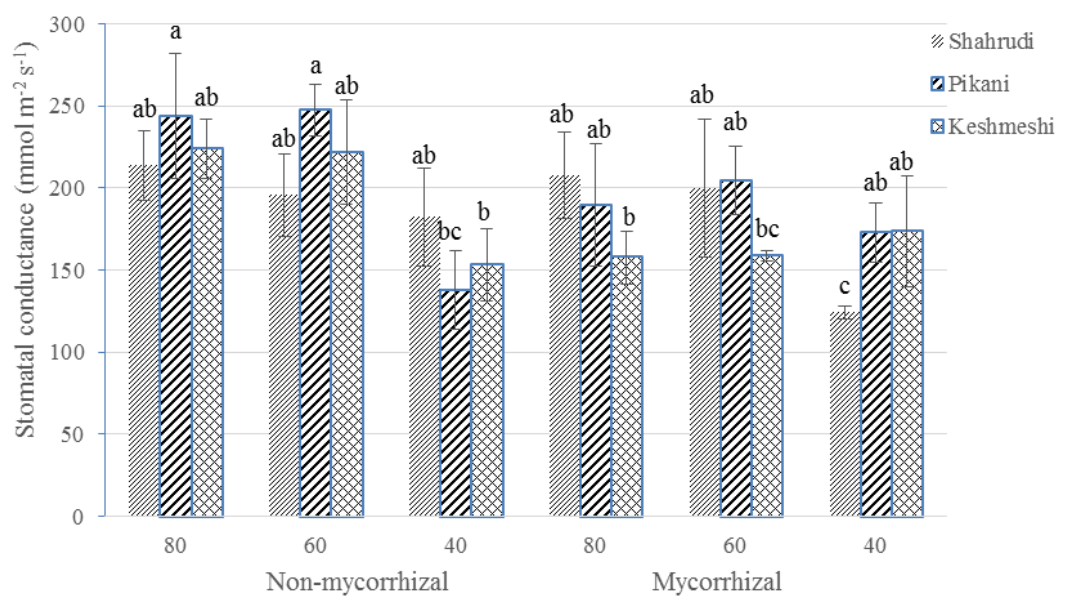

Fig 1. The effects of cultivars ('Shahroudi', 'Pikani', and 'Keshmeshi'), water deficit levels (field capacity (FC\%, 80, 60, and 40), and mycorrhizal (mycorrhizal and non- mycorrhizal) on Stomatal conductance in studied grape cultivars.

Table 2. The effects of cultivar and mycorrhizal on some growth characteristics of three Iranian grape cultivars.

\begin{tabular}{lllcc}
\hline Cultivar & Mycorrhizal & No. of leaves & Fresh leaves weight (g) & Dry leaves weight (g) \\
\hline \multirow{2}{*}{ Shahrudi } & Non-mycorrhizal & $12.33 \pm 1.41^{\mathrm{bz}}$ & $8.22 \pm 1.07^{\mathrm{ab}}$ & $2.10 \pm 0.25^{\mathrm{ab}}$ \\
& Mycorrhizal & $19.66 \pm 2.56^{\mathrm{ab}}$ & $9.42 \pm 1.14^{\mathrm{ab}}$ & $2.26 \pm 0.26^{\mathrm{ab}}$ \\
\multirow{2}{*}{ Pikani } & Non-mycorrhizal & $17.07 \pm 2.55^{\mathrm{ab}}$ & $5.04 \pm 1.19^{\mathrm{b}}$ & $1.64 \pm 0.27^{\mathrm{b}}$ \\
& Mycorrhizal & $22.30 \pm 2.82^{\mathrm{a}}$ & $8.07 \pm 1.11^{\mathrm{ab}}$ & $2.18 \pm 0.27^{\mathrm{ab}}$ \\
\multirow{2}{*}{ Keshmeshi } & Non-mycorrhizal & $18.60 \pm 2.06^{\mathrm{ab}}$ & $11.99 \pm 1.08^{\mathrm{a}}$ & $3.23 \pm 0.27^{\mathrm{a}}$ \\
& Mycorrhizal & $17.00 \pm 1.57^{\mathrm{ab}}$ & $9.64 \pm 1.18^{\mathrm{ab}}$ & $2.66 \pm 0.25^{\mathrm{ab}}$ \\
\hline
\end{tabular}

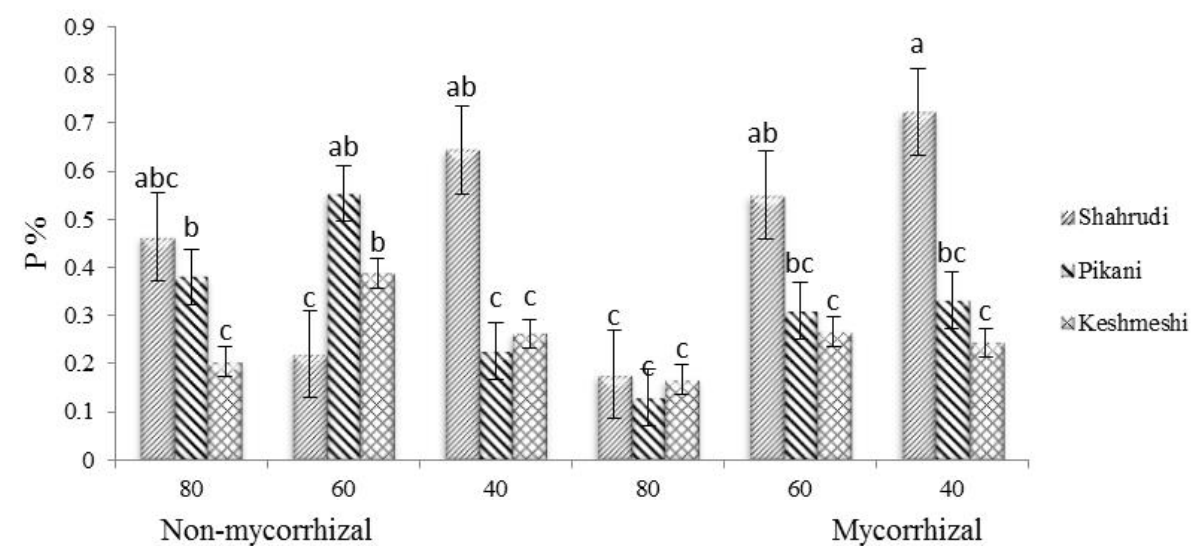

Fig 2. The effects of cultivars ('Shahroudi', 'Pikani', and 'Keshmeshi'), water deficit levels (field capacity (FC\%, 80, 60, and 40), and mycorrhizal (mycorrhizal and non- mycorrhizal) on leaf phosphorus concentration (P\%) in studied grape cultivars. 
Table 3. The effects of mycorrhizal fungi, Glomus mosseae, on some of the growth parameters of three grape cultivars under water deficit levels (irrigation in three field capacity (FC\%).

\begin{tabular}{|c|c|c|c|c|c|c|c|c|}
\hline & Cultivar & $\begin{array}{l}\text { Water } \\
\text { deficit } \\
\text { (FC\%) }\end{array}$ & Node number & $\begin{array}{c}\text { Fresh current } \\
\text { season shoot } \\
\text { weight (g) }\end{array}$ & $\begin{array}{c}\text { Dry current season } \\
\text { shoot weight (g) }\end{array}$ & $\begin{array}{c}\text { current season } \\
\text { shoot length }(\mathrm{cm})\end{array}$ & $\begin{array}{l}\text { Root length } \\
(\mathrm{cm})\end{array}$ & $\begin{array}{l}\text { Dry root weight } \\
\text { (g) }\end{array}$ \\
\hline \multirow{9}{*}{ Non-mycorrhizal } & \multirow{3}{*}{ Shahrudi } & 80 & $25 \pm 4.46^{\mathrm{a}-\mathrm{d} Z}$ & $7.5 \pm 0.92^{\text {bcd }}$ & $2.40 \pm 0.37^{\text {bcd }}$ & $25.4 \pm 3.38^{\mathrm{ab}}$ & $31.8 \pm 2.49^{c}$ & $10.94 \pm 2.31^{b}$ \\
\hline & & 60 & $17.6 \pm 2.66^{d}$ & $5.6 \pm 0.94^{\text {b-e }}$ & $1.66 \pm 0.37^{b-e}$ & $27.2 \pm 2.63^{a b}$ & $43.4 \pm 6.69^{b}$ & $11.04 \pm 1.45^{\mathrm{ab}}$ \\
\hline & & 40 & $19.6 \pm 1.21^{\mathrm{cd}}$ & $6.7 \pm 1.26^{\text {b-e }}$ & $2.68 \pm 0.65^{\mathrm{bc}}$ & $27.8 \pm 4.33^{a b}$ & $42.8 \pm 6.51 b$ & $9.88 \pm 0.37^{b c}$ \\
\hline & \multirow{3}{*}{ Pikani } & 80 & $24.25 \pm 2.87^{a-d}$ & $5.5 \pm 0.77^{\text {cde }}$ & $2.18 \pm 0.52^{b c d}$ & $20 \pm 2.79^{\mathrm{d}-\mathrm{g}}$ & $35.5 \pm 2.5^{b c}$ & $7.675 \pm 1.17^{\text {cde }}$ \\
\hline & & 60 & $31.4 \pm 1.25^{a b}$ & $4.7 \pm 0.83^{\mathrm{de}}$ & $1.34 \pm 0.40^{\text {ef }}$ & $21.4 \pm 2.23^{c-g}$ & $52.4 \pm 6.50^{a}$ & $6.48 \pm 0.84^{\mathrm{de}}$ \\
\hline & & 40 & $27.25 \pm 2.46^{a b c}$ & $4.6 \pm 0.31^{\text {de }}$ & $1.63 \pm 0.09^{\text {def }}$ & $18.75 \pm 2.36^{\mathrm{efg}}$ & $50.25 \pm 14.9^{a b}$ & $8.22 \pm 1.56^{b c d}$ \\
\hline & \multirow{3}{*}{ Keshmeshi } & 80 & $25.4 \pm 5.24^{a-d}$ & $7.5 \pm 1.93^{b c}$ & $2.74 \pm 0.97^{b}$ & $25.4 \pm 4.14^{a b}$ & $29.4 \pm 2.15^{c}$ & $10.34 \pm 0.95^{b c}$ \\
\hline & & 60 & $23 \pm 2.32^{b c d}$ & $6.1 \pm 0.46^{\mathrm{b}-\mathrm{e}}$ & $2.18 \pm 0.20^{b c d}$ & $27.1 \pm 2.51^{a b}$ & $38 \pm 4.14^{b}$ & $11.2 \pm 1.32^{\mathrm{ab}}$ \\
\hline & & 40 & $17 \pm 1.70^{d}$ & $4.2 \pm 0.20^{e f}$ & $1.50 \pm 0.14^{\text {def }}$ & $18.8 \pm 3.6^{a b c}$ & $28.6 \pm 2.61^{c}$ & $7.96 \pm 0.55^{\text {cde }}$ \\
\hline \multirow{9}{*}{ Mycorrhizal } & \multirow{3}{*}{ Shahrudi } & 80 & $33.6 \pm 2.09^{a}$ & $8.5 \pm 0.93^{a}$ & $2.96 \pm 0.30^{\mathrm{a}}$ & $28.2 \pm 4.82^{a b}$ & $29.8 \pm 2.41^{c}$ & $12.58 \pm 2.74^{a}$ \\
\hline & & 60 & $28.4 \pm 2.50^{\mathrm{abc}}$ & $7.7 \pm 1.45^{b}$ & $2.30 \pm 0.54^{b c d}$ & $32.3 \pm 3.46^{\mathrm{a}}$ & $43.6 \pm 5.51^{b}$ & $11.74 \pm 2.02^{\mathrm{a}}$ \\
\hline & & 40 & $21.4 \pm 2.06^{\mathrm{cd}}$ & $4.0 \pm 0.87^{\mathrm{e}}$ & $1.10 \pm 0.19^{\mathrm{efg}}$ & $20.2 \pm 3.95^{\mathrm{efg}}$ & $40.1 \pm 2.9^{b}$ & $12.98 \pm 2.04^{a}$ \\
\hline & \multirow{3}{*}{ Pikani } & 80 & $32 \pm 4.43^{a b}$ & $7.1 \pm 2.15^{b c}$ & $2.53 \pm 0.73^{b c}$ & $24 \pm 2.54^{b}$ & $34 \pm 4.88^{b c}$ & $7.95 \pm 1.09^{\text {cde }}$ \\
\hline & & 60 & $31.2 \pm 1.43^{\mathrm{ab}}$ & $7.4 \pm 2.06^{b}$ & $2.22 \pm 0.71^{\mathrm{bcd}}$ & $26.7 \pm 5.61^{\mathrm{abc}}$ & $37.3 \pm 6.60^{b c}$ & $8.84 \pm 1.16^{\mathrm{bc}}$ \\
\hline & & 40 & $17.25 \pm 1.31^{d}$ & $2.3 \pm 0.51^{\dagger}$ & $0.58 \pm 0.11^{\mathrm{g}}$ & $14.75 \pm 1.05^{\mathrm{g}}$ & $35 \pm 7.32^{b}$ & $7.62 \pm 0.82^{\text {cde }}$ \\
\hline & \multirow{3}{*}{ Keshmeshi } & 80 & $31 \pm 1.87^{\mathrm{ab}}$ & $7.0 \pm 0.52^{b c}$ & $2.38 \pm 0.28^{b c d}$ & $25.6 \pm 4.05^{b}$ & $30.2 \pm 3.38^{c}$ & $10.58 \pm 0.54^{b}$ \\
\hline & & 60 & $25.2 \pm 1.91^{a-d}$ & $5.0 \pm 0.41^{\text {cde }}$ & $1.38 \pm 0.18^{\text {ef }}$ & $26 \pm 1.25^{\mathrm{abc}}$ & $47.6 \pm 7.20^{b}$ & $11.12 \pm 1.97^{a b}$ \\
\hline & & 40 & $20.75 \pm 1.93^{\mathrm{cd}}$ & $4.6 \pm 0.64^{\text {def }}$ & $1.25 \pm 0.16^{\mathrm{fg}}$ & $23.75 \pm 4.73^{b c}$ & $39.5 \pm 5.67^{b}$ & $8.3 \pm 0.58^{b c d}$ \\
\hline
\end{tabular}

Z : Mean \pm Standard Error., Different letters within columns indicate significant differences among the treatments according to Duncan Test $(P<0.05)$.

Table 4. The mean comparison of total fresh weight, the fresh and dry weight of roots, leaf Stomatal conductance and relative water content (RWC) in pot growing three Iranian grape cultivars under water deficit condition and mycorrhizal fungi incubation.

\begin{tabular}{lccccc}
\hline cultivar & Total fresh weight (g) & Fresh root weight (g) & Dry root weight (g) & $\begin{array}{c}\text { Stomatal conductance } \\
\left(\mathrm{mmol} \mathrm{m}^{-2} \mathrm{~s}^{-1}\right)\end{array}$ \\
\hline Shahrudi & $84.40 \pm 4.05^{\mathrm{a}}$ & $35.63 \pm 2.17^{\mathrm{a}}$ & $11.52 \pm 0.75^{\mathrm{a}}$ & $208.33 \pm 11.4^{\mathrm{a}}$ & $82.22 \pm 0.922^{\mathrm{b}}$ \\
Pikami & $69.78 \pm 2.84^{\mathrm{b}}$ & $27.84 \pm 1.35^{\mathrm{b}}$ & $7.78 \pm 0.48^{\mathrm{c}}$ & $205.15 \pm 11.7^{\mathrm{a}}$ & $83.24 \pm 0.72^{\mathrm{ab}}$ \\
Kehsmeshi & $74.89 \pm 3.65^{\mathrm{ab}}$ & $30.50 \pm 1.36^{\mathrm{b}}$ & $9.97 \pm 0.49^{\mathrm{b}}$ & $167.90 \pm 9.4^{\mathrm{b}}$ & $85.16 \pm 0.699^{\mathrm{a}}$ \\
\hline
\end{tabular}

Table 5. The Effect of water deficit on some growth characteristics of three Iranian grape cultivars.

\begin{tabular}{|c|c|c|c|c|c|c|}
\hline $\begin{array}{l}\text { Water deficit } \\
\text { FC\% }\end{array}$ & $\begin{array}{c}\text { Fresh leaves } \\
\text { weight }\end{array}$ & Dry leaves weight & $\begin{array}{c}\text { Total fresh } \\
\text { weight }\end{array}$ & Nitrogen \% & $\begin{array}{c}\text { Relative water } \\
\text { content }\end{array}$ & $\begin{array}{c}\text { Proline } \\
\left(\mathrm{mg} \mathrm{g}^{-1} \mathrm{dw}\right)\end{array}$ \\
\hline 80 & $10.14 \pm 0.82^{a}$ & $2.99 \pm 0.19^{a}$ & $84.11 \pm 4.58 a$ & $2.47 \pm 0.12^{a}$ & $84.82 \pm 0.84^{a}$ & $0.32 \pm 0.05^{b}$ \\
\hline 60 & $7.54 \pm 0.77^{b}$ & $1.78 \pm 0.18^{b}$ & $77.80 \pm 3.05 a b$ & $2.28 \pm 0.13^{a}$ & $84.36 \pm 0.58^{a}$ & $0.43 \pm 0.03^{a}$ \\
\hline 40 & $3.37 \pm 0.68^{c}$ & $1.13 \pm 0.16^{c}$ & $67.95 \pm 2.90 \mathrm{~b}$ & $1.92 \pm 0.08^{b}$ & $81.28 \pm 0.90^{b}$ & $0.44 \pm 0.04^{a}$ \\
\hline
\end{tabular}

Table 6. Pearson correlation among some physiological, NPK and growth characters in pot growing three Iranian grape cultivars under water deficit condition and mycorrhizal fungi incubation

\begin{tabular}{|c|c|c|c|c|c|c|c|c|c|c|}
\hline 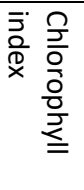 & 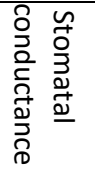 & $\sum_{n}^{\infty}$ & 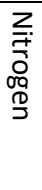 & 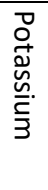 & $\begin{array}{l}\frac{0}{0} \\
0 \\
\frac{\hat{n}}{0} \\
\frac{0}{0} \\
\frac{0}{0}\end{array}$ & 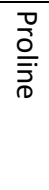 & 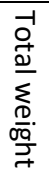 & $\begin{array}{l}\text { D } \\
\stackrel{O}{+} \\
\frac{D}{D} \\
\stackrel{o g}{\sigma} \\
\frac{q}{J}\end{array}$ & 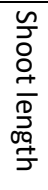 & 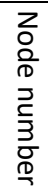 \\
\hline
\end{tabular}

\begin{tabular}{|c|c|c|c|c|c|c|c|c|c|c|c|}
\hline Chlorophyll index & 1 & & & & & & & & & & \\
\hline Stomatal conductance & -0.10 & 1 & & & & & & & & & \\
\hline RWC & $0.28 * *$ & $-0.31 * *$ & 1 & & & & & & & & \\
\hline Nitrogen & -0.13 & 0.05 & 0.16 & 1 & & & & & & & \\
\hline Potassium & $-0.30 * *$ & 0.02 & -0.05 & $-0.25^{*}$ & 1 & & & & & & \\
\hline Phosphor & -0.07 & 0.08 & -0.06 & 0.16 & 0.08 & 1 & & & & & \\
\hline Proline & 0.09 & -0.03 & -0.10 & 0.04 & 0.02 & 0.03 & 1 & & & & \\
\hline Total weight & -0.06 & -0.12 & 0.13 & $0.25^{*}$ & 0.02 & 0.05 & -0.04 & 1 & & & \\
\hline Root length & -0.04 & $0.25 *$ & $-0.27 * *$ & -0.04 & 0.08 & 0.16 & -0.04 & -0.20 & 1 & & \\
\hline Shoot length & 0.06 & -0.06 & $0.24^{*}$ & $0.28 *$ & 0.06 & -0.02 & -0.07 & $0.23 *$ & -0.04 & & \\
\hline Node number & 0.08 & 0.16 & $0.21 *$ & $0.42 * *$ & 0.11 & 0.10 & -0.10 & $0.31 * *$ & 0.10 & $0.28 * *$ & 1 \\
\hline
\end{tabular}

*. Correlation is significant at the 0.05 level. 
play key roles in plant adaptation to drought stress (Farooq et al., 2009). In respond to water deficit, plants usually reduce the leaf number and leaf area to decrease the water budget for the cost of reduced performance. Research has been shown that drought stress reduced the number of leaf vines and ultimately reduced growth (FanizzaRicciardi, 2015), which the current study also confirmed that absorbing enough water by the plant is one of the main factors in responding to drought. Roots are the only part to obtain water from the soil, the root growth such as; length, density, size, weights, etc. are critical for plants to overcome drought stress (Farooq et al., 2009). In this study, we observed that 'Pikani' had the longest root at the water deficit of $60 \%$ (Table 3). Reducing the aerial parts weight by the plant is an obvious response to the drought stress. In addition, it has been noted that under drought stress, plants reduce root weight (Farooq et al., 2009; FanizzaRicciardi, 2015). The results of this experiment also indicated that with increasing the water deficit level, a reduction in aerial parts and root weight was observed. The results indicated a potential for 'Pikani' to be used for selecting droughttolerant rootstock in grape.

The results of the current study are indicating that the highest number of leaves produced by AMF vines (Table 2). The most substantial fresh and dry stem weight, the highest number of internode, and the most root length was observed in water deficit of $60 \%$ with AMF (Table 3 ). Also, the highest root dry weight was recorded at water deficit of $40 \%$ with AMF (Table 3). Enhancement of vegetative growth by AMF treatment has already been reported by researchers in some species, including grape (Caravaca et al., 2005; Wu et al., 2006; Smith et al., 2011; Trouvelot et al., 2015). The ability of the AMF treatment to enhance the growth in some grape rootstocks and cultivars has been reported, although the response to the treatments among rootstocks and cultivars was reported differently (Schreiner, 2005; Eftekhari et al., 2012; Trouvelot et al., 2015). Also in this study, respond to AMF symbiosis was different among studied cultivars, whereas 'Shahroudi' showed a better symbiosis than other two cultivars (Table 2). AMF symbiosis in agricultural systems is the most well-known type of relationship. In this mutual symbiosis, the host plant consumes the minerals and water obtained by fungus, and the host plant provides carbohydrates consumed by the fungus (Smith et al., 2011; Rouphael et al., 2015). In addition to providing nutrients, some other potential benefits of AMF colonization of host plants include growth and increased resistance to pathogens and other environmental stresses (Smith et al., 2011; Trouvelot et al., 2015).

The stomatal conductance decreased with increasing drought stress in $40 \%$ of field capacity and without AMF. At all three levels of water deficit, stomatal conductance was more in AMF than without AMF. The effect on stomatal conductance showed 'Shahroudi', and 'Pikani' has a higher stomatal conductance than 'Keshmeshi'. The results showed that the stomatal conductance decreased with increasing drought stress and the correlation analysis show that when the stomatal conductance decrease leaf relative water content was increased. Plants have specific mechanisms to deal with drought conditions to increase water-use efficiency. Closing leaf stomatal is the initial response of plants to drought stress. Mechanism of stomatal opening and closing in many plants, as well as grapes, are classified into two types of isohydric and anisohydric(HugaldeVila, 2014). In the group of isohydric, the stomata are closed in potential water reduction, while in the other group stomatal are not closed in medium stress condition. Several studies showed that grape varieties with anisohydric properties can tolerate medium stress conditions and return faster to the original state (Pou et al., 2012). Gradual reduction of photosynthesis and stomatal conductance with increasing drought stress even under stress is one of the characteristics of plants adapted to drought (Farooq et al., 2009; FanizzaRicciardi, 2015). AMF colonization accelerates nutrient uptake and most possibly upsurges photosynthetic rates in grapevine (Mortimer et al., 2005; Merli et al., 2015). However, available data on AMF to increase the photosynthetic rate in grapevine is limited and confusing (Trouvelot et al., 2015). Results of this study show that stomatal conductance rates are lower in AMF treatment compared to those with no AMF (Fig 1).

The results of RWC of leaf tissue showed that 'Keshmeshi' had more RWC (85.16\%) in leaf tissue than the other two cultivars. With increasing drought stress level, relative water content decreases (Table 5). According to Flexas et al. (2004) photosynthesis in some species such as grape decreases progressively with increasing drought stress level without a reduction in the RWC. Thus, the cultivars that hold the RWC higher under drought stress can be introduced as a cultivar more tolerant to drought stress (Flexas et al., 2004).

The results of the proline measurement in the fresh leaves showed that with increasing drought the proline level increased, where at the water deficit of $40 \%$, the leaf had the maximum proline content (Table 4). Valentine et al. (2006) reported an accumulation of proline with increasing drought stress level in grapevine. Proline is an essential amino acid for plants that increase under drought stress and is not toxic in high concentrations. Proline help plant to uptake water under the drought condition by lowering the water potential of the roots, it could perform as a sink for energy to adjust redox capabilities under drought stress (Ankita et al., 2017).

Leaf nutrient analysis results showed that with increasing drought stress the leaf nitrogen content reduced where the lowest amount of nitrogen (1.92\%) was observed at the water deficit of $40 \%$ (Table 5). Drought stress also increased the leaf phosphorus content in 'Shahroodi' with and without AMF. Research showed that an increase in water deficit causes a reduction in the content of the nutritive element, particularly for nitrogen and phosphorus(Farooq et al., 2009). Water stress in non-irrigated vines reduced leaf chlorophyll and nitrogen level consequently. Water flow accompanies the soil-root-shoot pathway is important for the vine to uptake nutrient from the soil (Gonzalez-Dugo et al., 2010; Keller et al., 2016). As shown in Table 1; AMF and water deficit increased the leaf potassium content significantly $(p \leq 0.05)$. Increased potassium was higher in 'Keshmeshi' than other two cultivars. Potassium is one of the most cations, which is required by plants that accumulate during osmotic stress to regulate osmotic pressure and stomatal. The symbiosis of AMF with some plant species under water stress conditions increases the amount nutrition elements significantly (Smith et al., 2011; Trouvelot et al., 2015). However, the results showed that AMF have the only positive effect of phosphor absorption in water deficient condition. It seems that an increase in the 
absorption of nutrients by AMF plants is due to the development of mycelium associated with the internal root tissues and an additional uptake system supplemental to the plant root, which allow to the root to access to larger volumes of soil that are inaccessible to feeder roots without AMF.

\section{Conclusion}

Water deficit can affect grapevine growth significantly; morphological characteristics such as leaf, shoot, and root are the most affected parts. By increasing the water deficit level, a reduction in aerial parts and root weight was observed. The number of leaves obviously increase in vines inoculated by AMF. 'Shahroudi' and 'Pikani' has a higher stomatal conductance than 'Keshmeshi' and show an isohydric behavior. Finally, we can conclude that mycorrhiza inoculation can demolish the effects of drought stress and can be used as an anti-stress agent in vineyards. However, the response to the mycorrhiza varied among the studied cultivars.

\section{Materials and methods}

\section{Plant materials}

Three important cultivars of grapes including 'Shahrudi', 'Pikani', and 'Keshmeshi' were chosen. This cultivar is mainly cultivated in the vineyard of Shahrood and Sabzevar areas, The main grape producing areas, in north and northeast of Iran.

\section{Experiment location}

The field and laboratory tests were done at the Shahrood University of Technology, located within the Bastam region ( $36^{\circ} 25^{\prime} 05^{\prime \prime} \mathrm{N}$ and $5458^{\prime} 35^{\prime \prime}$ ) during 2014-2016 seasons.

\section{Vine cultivation}

One-year-old vines Vitis vinifera cv. 'Shahrudi', 'Pikani', and 'Keshmeshi' were purchased from a commercial supplier (Agro-industry, Joeyn, Iran) and five vines (pots) were used per treatment. The plants were established in eight-liter pots filled with sterilized loam-sand. For the AMF treatments, $100 \mathrm{~g}$ of live mycorrhizal inoculum (substrate, Glomus mosseae, Toran Biotech, Shahrood-Iran) placed under the root of vines in each pot before planting. Vines were grown as a tunnel greenhouse for three months, considering as inoculation establishment time. During this time, all treatments received a similar horticultural practice such as irrigation, nutrient, etc. Vines were pruned to keep a single shoot per vine.

\section{Treatments}

After 12 weeks following transplantation and inoculation, the vines were gone under-water deficit for two months based on the field capacity (FC); FC $80 \%$ as a control, FC $60 \%$ as a moderate water deficit, and FC $40 \%$ as a severe water deficit. The mean weight of the soil moisture was calculated from five pots, then water deficit level considered as FC\% moisture percentage and the amount calculated as gram water $\left(\mathrm{H}_{2} \mathrm{O}\right)$. To achieve the desired moisture content or FC\% in all treatments, the calculated amount water $(\mathrm{g})$ was added to each pot (treatment). During water deficit time, only the water supply was varied among the treatments, and all other practical practices such as nutrient supply remained the same for all treatments.

\section{Measurement of growth characteristics and physiological parameters}

At the end of the experiment period, growth characteristics such as; shoot length, root length (ruler $\mathrm{mm}$ ), the number of leaves, the number of internodes, leaf area index, fresh and dry weights of the different parts were recorded. To measure the fresh and dry weight an analytical scale with the precision of $0.001 \mathrm{~g}$ was used. Plants pulled out from the pot, and after cleaning the root, they were divided into different parts (root, shoot, leaf). After measuring the fresh weight, different parts are placed into the oven at $65^{\circ} \mathrm{C}$ for $48 \mathrm{~h}$ to record the dry weight. Chlorophyll index was measured by a SPAD 502 set (Minolta Camera Co., Osaka, Japan). An SC-1 Porometer (Decagon Devices, WA, USA ) was used to measure stomatal conductance. Chlorophyll index and stomatal conductance were measured seven weeks after the water deficit induced on leaves number 8 and 9 from each vine during $11 \mathrm{am}$ to $1 \mathrm{pm}$ before irrigation applied.

Leaf relative water content (RWC) was obtained based on the methods of (YamasakiDillenburg, 1999). Single leaves were first detached from the stem and then weighed to record fresh mass (FM) at the harvest point. To determine the turgid mass (TM), leaves was floated in deionized water inside a sealed Petri plate for $24 \mathrm{~h}$ in low light density condition at $4^{\circ} \mathrm{C}$, then leaf surface wiped gently with the tissue paper from the water. To obtain the dry mass (DM), leaf samples were located in a pre-heated oven at $70^{\circ} \mathrm{C}$ for $48 \mathrm{~h}$. An analytical scale with a precision of $0.0001 \mathrm{~g}$ was used for doing the measurements. FM, TM and DM Values were used to determine RWC using the following equation;

$\mathrm{RWC}(\%)=[(\mathrm{FM}-\mathrm{DM}) /(\mathrm{TM}-\mathrm{DM})] \times 100$

The proline concentration of the freshly harvested leaves was determined using a spectrophotometer (Perkin Elmer, Lambda EZ201, CA, USA) at $520 \mathrm{~nm}$ based on the ninhydrin method explained by (Bates et al., 1973).

\section{Measurements of nitrogen (N), phosphorus $(P)$ and potassium (K)}

The dried leave samples were powdered using a pestle and mortar. Grounded samples were placed at $550^{\circ} \mathrm{C}$ for $6 \mathrm{~h}$. The ash was mixed up with $2 \mathrm{M}$ hot $\mathrm{HCl}$, then filtered into a 50 $\mathrm{mL}$ flask and made up to $50 \mathrm{~mL}$ with deionized water. Phosphorus was determined in these sample solutions using a UV/visible spectrophotometer (Perkin Elmer, Lambda EZ201, CA, USA) at 470nm. Potassium was determined based on Atomic Emission Spectrometry's method using a flame photometer set (Corning 400, Sheffield, UK). Using the semiautomatic Kjeldahl set (Vapodest 20S, Gerhardt, Königswinter, Germany) total $\mathrm{N}$ was determined in $0.1 \mathrm{~g}$ dried weighted samples (ChapmanPratt, 1982). 


\section{Statistical analysis}

The experiment was laid out as a completely randomized design (CRD) with three factorial combination and five replications of each treatment combination, which are completely randomized in greenhouse condition. The three factors were including: first- the three grape cultivars ('Shahrudi', 'Pikani', and 'Keshmeshi'), second- arbuscular mycorrhizal inoculation and non-inoculation, and thirdthree different levels of water deficit based on field capacity (FC); FC $80 \%$ as a control, FC $60 \%$ as a moderate water deficit, and FC $40 \%$ as a severe water deficit. Data were analyzed by analysis of variance (ANOVA), mean treatment differences among the treatments were tested at $P<0.05$ by Duncan test. SAS, version 9.3 statistical software (SAS Institute, Cary, NC, USA) was used for data analyzing. A Pearson correlation among traits was done with SPSS 17.

\section{Acknowledgments}

Authors are thankful to the Shahrood University of Technology for supporting this study.

\section{References}

Ankita S, Surinder K, Alok K, Gill R, Sarvjeet S (2017) Proline Content and Membrane Permeability Index in Response to Water Stress in Recombinant Inbred Lines of Lentil. Vegetos-An Inter. J. of Plant Res. 30: 63-72.

Awasthi R, Kaushal N, Vadez V, Turner NC, Berger J, Siddique KH Nayyar H, (2014) Individual and combined effects of transient drought and heat stress on carbon assimilation and seed filling in chickpea. Funct. Plant Biol. 41: 11481167.

Balestrini R, Magurno F, Walker C, Lumini E Bianciotto V (2010) Cohorts of arbuscular mycorrhizal fungi (AMF) in Vitis vinifera, a typical Mediterranean fruit crop. Environ. Microbiol. Rep. 2: 594-604.

Bates L, Waldren R Teare I (1973) Rapid determination of free proline for water-stress studies. Plant and soil. 39: 205-207.

Bota J, Tomás M, Flexas J, Medrano H, Escalona J (2016) Differences among grapevine cultivars in their stomatal behavior and water use efficiency under progressive water stress. Agric Water Manag. 164: 91-99.

Caravaca F, Alguacil M, Hernández J, Roldán A (2005) Involvement of antioxidant enzyme and nitrate reductase activities during water stress and recovery of mycorrhizal Myrtus communis and Phillyrea angustifolia plants. Plant Sci. 169: 191-197.

Chapman H. Pratt F (1982) Methods of analysis soils plant and water, university of California. Agriculture Division, USA 169.

Chaves M, Costa J, Zarrouk O, Pinheiro C, Lopes C, Pereira J (2016) Controlling stomatal aperture in semi-arid regions-The dilemma of saving water or being cool? Plant Sci. 251: 54-64.

Chaves MM, Zarrouk O, Francisco R, Costa JM, Santos T, Regalado AP, Rodrigues ML Lopes CM (2010) Grapevine under deficit irrigation: hints from physiological and molecular data. Ann. Bot. 105: 661-676.
Eftekhari M, Alizadeh M, Mashayekhi K, Asghari H (2012) In vitro propagation of four Iranian grape varieties: Influence of genotype and pretreatment with arbuscular mycorrhiza. Vitis 51: 175-182.

Essahibi A, Benhiba, L, Babram, MA, Ghoulam, C Qaddoury, A, (2018) Influence of arbuscular mycorrhizal fungi on the functional mechanisms associated with drought tolerance in carob (Ceratonia siliqua L.). Trees 32: 87-97.

Fanizza G, Ricciardi L (2015) Influence of drought stress on shoot, leaf growth, leaf water potential, stomatal resistance in wine grape genotypes (Vitis vinifera L.). VITISJournal of Grapevine Research 29: 371.

Farooq M, Wahid A, Kobayashi N, Fujita D, Basra S (2009) Plant drought stress: effects, mechanisms and management. Sustainable agriculture. Springer, pp. 153188.

Flexas J, Bota J, Cifre J, Mariano Escalona J, Galmés J, Gulías J, Lefi EK, Florinda Martínez-Cañellas S, Teresa Moreno M, Ribas-Carbó M, Riera D, Sampol B, Medrano H (2004) Understanding down-regulation of photosynthesis under water stress: future prospects and searching for physiological tools for irrigation management. Ann Appl Biol. 144: 273-283.

Gonzalez-Dugo V, Durand J-L Gastal F (2010) Water deficit and nitrogen nutrition of crops. A review. Agron Sustain Dev. 30: 529-544.

Hameed A, Wu Q-S, Abd-Allah EF, Hashem A, Kumar A, Lone HA, Ahmad P (2014) Role of AM fungi in alleviating drought stress in plants. Use of Microbes for the Alleviation of Soil Stresses. Springer, pp. 55-75.

Hashem A, Abd_Allah EF, Alqarawi AA Egamberdieva D (2018) Arbuscular Mycorrhizal Fungi and Plant Stress Tolerance. Plant Microbiome: Stress Response. Springer, pp. 81-103.

Hugalde I, Vila H (2014) Isohydric or anisohydric behavior on vines.... an endless controversy? RIA, Revista de Investigaciones Agropecuarias 40: 75-82.

Keller M, Romero P, Gohil H, Smithyman RP, Riley WR, Casassa LF Harbertson JF (2016) Deficit irrigation alters grapevine growth, physiology, and fruit microclimate. Am. J. Enology Vitic: 67: 426-435.

Kohler J, Hernández JA, Caravaca F, Roldán A (2008) Plantgrowth-promoting rhizobacteria and arbuscular mycorrhizal fungi modify alleviation biochemical mechanisms in water-stressed plants. Funct. Plant Biol. 35: 141-151.

Medrano H, Tortosa I, Montes E, Pou A, Balda P, Bota J, Escalona JM (2018) Genetic Improvement of Grapevine (Vitis vinifera L.) Water Use Efficiency: Variability Among Varieties and Clones. Water Scarcity and Sustainable Agriculture in Semiarid Environment. Elsevier, pp. 377-401. Merli MC, Gatti M, Galbignani M, Bernizzoni F, Magnanini E, Poni S (2015) Water use efficiency in Sangiovese grapes (Vitis vinifera $\mathrm{L}$.) subjected to water stress before veraison: different levels of assessment lead to different conclusions. Funct. Plant Biol. 42: 198-208.

Mortimer P, Archer E, Valentine A (2005) Mycorrhizal C costs and nutritional benefits in developing grapevines. Mycorrhiza. 15: 159-165.

Permanhani $M$, Costa JM, Conceição $M$, de Souza $R$, Vasconcellos M, Chaves M (2016) Deficit irrigation in table grape: eco-physiological basis and potential use to save 
water and improve quality. Theor. Exp. Plant Physiol. 28: 85-108.

Pou A, Medrano $H$, Tomàs $M$, Martorell $S$, Ribas-Carbó $M$, Flexas J (2012) Anisohydric behaviour in grapevines results in better performance under moderate water stress and recovery than isohydric behaviour. Plant Soil. 359: 335349.

Rouphael Y, Franken P, Schneider C, Schwarz D, Giovannetti M, Agnolucci M, De Pascale S, Bonini P Colla G (2015) Arbuscular mycorrhizal fungi act as biostimulants in horticultural crops. Sci Hort. 196: 91-108.

Schreiner RP (2005) Mycorrhizas and mineral acquisition in grapevines. Proceedings of the soil environment and vine mineral nutrition symposium. American Society for Enology and Viticulture, ASEV, p.^pp: 49-60.

Schreiner RP, Mihara KL (2009) The diversity of arbuscular mycorrhizal fungi amplified from grapevine roots (Vitis vinifera L.) in Oregon vineyards is seasonally stable and influenced by soil and vine age. Mycol. 101: 599-611.

Smith SE, Jakobsen I, Granlund M, Smith FA (2011) Roles of arbuscular mycorrhizas in plant phosphorus nutrition: interactions between pathways of phosphorus uptake in arbuscular mycorrhizal roots have important implications for understanding and manipulating plant phosphorus acquisition. Plant physiol. 156: 1050-1057.
Teskey R, Wertin T, Bauweraerts I, Ameye M, McGuire MA, Steppe K (2015) Responses of tree species to heat waves and extreme heat events. Plant Cell Environ. 38: 16991712.

This P, Lacombe T, Thomas MR (2006) Historical origins and genetic diversity of wine grapes. Trends Genet. 22: $511-$ 519.

Trouvelot S, Bonneau L, Redecker D, Van Tuinen D, Adrian M, Wipf D (2015) Arbuscular mycorrhiza symbiosis in viticulture: a review. Agron. Sustain. Dev. 35: 1449-1467.

Valentine A, Mortimer P, Lintnaar M, Borgo R (2006) Drought responses of arbuscular mycorrhizal grapevines. Symbiosis. 41: 127-133.

Wu Q, Xia R, Hu Z (2006) Effect of arbuscular mycorrhiza on the drought tolerance of Poncirus trifoliata seedlings. Fron fores. Ch. 1: 100-104.

Xu L, Li T, Wu Z, Feng H, Yu M, Zhang X, Chen B (2018) Arbuscular mycorrhiza enhances drought tolerance of tomato plants by regulating the 14-3-3 genes in the ABA signaling pathway. Applied Soil Ecology.

Yamasaki S, Dillenburg LR (1999) Measurements of leaf relative water content in Araucaria angustifolia. Rev. Bras. Fisiol. Veg. 11: 69-75.

Zandalinas SI, Mittler R, Balfagón D, Arbona V, GómezCadenas A (2018) Plant adaptations to the combination of drought and high temperatures. Physiol. Plant. 162: 2-12. 